\title{
From Inquisition to E-Inquisition: A Survey of Online Sources on the Portuguese Inquisition
}

LILADHAR R. PENDSE

University of California, Berkeley

\begin{abstract}
The Portuguese Inquisition in the colonies of the Empire remains understudied due to a lack of primary source materials that are available the researchers and educators. The advances in digital technologies and the current drive to foster Open Access have allowed us to understand better the relations among the complex set of circumstances as well as the mechanisms that, in their totality, represent the Portuguese Inquisition. The present paper seeks to answer questions that vary from describing these resources to identifying the institutions that created them. Digitized resources serve as a surrogate of the originals, and we can leverage the access to these electronic surrogates and enhance our understanding of the mechanisms of inquisition through E-Inquisitional objects in pedagogy and research.
\end{abstract}

Keywords: Empire, Brazil, India, Africa, archives, open access

The study of the history of the Portuguese Inquisition and its institutions has acquired importance in the context of early efforts to convert, indoctrinate, organize and "civilize" the large native and indigenous populations over the vast global expanse of the Portuguese Empire. From the beginning, the Portuguese Crown formed an alliance with the Catholic Church to promote proselytization in its early colonial acquisitions in India. Moreover, the Inquisition was employed to maintain control and doctrinal consistency among the native populations throughout the empire. In this cursory work, I identify online primary 
and secondary sources on the Portuguese Inquisition that are in the public domain. The questions that I will attempt to answer are as follows:

1. What are some of the readily available online open access sources, both primary and secondary, on various aspects of the Portuguese Inquisition?

2. How are these resources organized?

3. What are some of the institutions of religious control that created these resources?

4. Which of these online sources highlight Inquisition documents within Portugal's imperial provinces and possessions?

The goal of this paper is to represent and describe the several primary and secondary sources on Portuguese Inquisition that are openly accessible. These resources can be used to foster understanding among students and researchers of the modalities and mechanisms of the Portuguese Inquisition.

\section{Literature Review}

Multiple sources describe the documentary evidence related to the Portuguese Inquisition in great detail. James E. Wadsworth describes the causes for the selective effectiveness and inadequate nature of Portuguese inquisitional authorities and processes in colonial Pernambuco, while providing a thorough analysis of some of these sources in the context of Brazil. Wadsworth also gives a general overview of inquisitorial institutions and their trajectory, along with the collaboration and cooperation of civilian and the local ecclesiastical authorities within colonial Brazil. The other important work related to the history of the Inquisition in Brazil's Northeastern provinces is Grayce Mayre Bonfim Souza's $2009 \mathrm{PhD}$ thesis. Her findings allude to the fact that in the territories of Northeastern Brazil, the institutions of a Lisbon-based tribunal devolved to a network of collaborative officials such as notaries, lay commissioners, and others, who provided not only the interpretation of laws related to the Inquisition but also implemented them in these territories. 
Sonia Aparecida de Silveira provides an in-depth account of most of the regimentos, a compilation of the laws that governed the inquisition in Brazil. She suggests that the Portuguese wanted to replicate their world in the new colony, and so royal, ecclesiastical, and inquisitorial laws and policies were applied to regulate the lives of the colonized. Silveira also provides a complete transcription of many of the regimentos that might serve as an important source on the Portuguese Inquisition in Brazil. However, this compilation of rules and regulations does not tell the whole story.

Inquisition trial transcripts and eyewitness accounts represent another important source for understanding the implementation mechanisms and the reach of the Portuguese Inquisition. The earliest comprehensive work dedicated to the history of Portuguese Inquisition is Alexandre Herculano's three-volume História da origem e estabelecimento da Inquisição em Portugal (1854), which traces the historical trajectory of inquisition from 1521 through 1821.

Antônio Joaquim Moreira has examined the periodization of the Portuguese Inquisition, while António Baião has focused on the Portuguese Inquisition in Goa. Baião claims that the documents concerning the Goa Inquisition from 1596, $1610,1619-1621,1636$ and 1690 were destroyed, so it is not possible to reconstruct information for the Portuguese colonies in East Africa during these years.

One must note that an additional corpus of secondary literature dedicated to the Inquisition in Portugal began to appear in the aftermath of the fall of the Salazarist regime (Marocci 359). As a result, recent descriptions of historical sources on the Inquisition are plentiful within Portugal, while descriptions of the same for Portugal's former colonies are much less so. Nevertheless, the colonies in India, such as Goa and the Northern Provinces, had to withstand the worst of the Inquisition to various degrees. For colonies like Goa, the problem lies in the fact that the records of Inquisition trials were burned in 1815 (Townsend 514). The inquisition in Goa not only led to the trials of Jews, heretics, Muslims, and Hindus but also abetted the continued selective destruction of local Hindu and Muslim shrines and places of worship (Axelrod 417). The Inquisition in Goa, with its 16,000 trials, was one of the most severe among Portuguese colonies (Murphy 166).

The surviving regimentos and other related documents can be fragile due to the passage of time and the conditions in which they appear to have been stored. 
For this reason, online access to digital surrogates of these resources becomes essential. Some researchers likewise experience travel constraints for various reasons, and therefore access to digital surrogates of the actual records enhances their ability to work effectively with the documents.

\section{On the Portuguese Inquisition}

This minimal overview is intended to contextualize the Portuguese Inquisition and its institutions while providing some insight on the documentation that this institution could have generated. The Portuguese Inquisition, along with its associated institutions, began under King João III in 1536 and lasted until its abolition in 1821. One must note that the Inquisition in Spain had preceded Portuguese efforts by almost fifty-eight years. The Spanish Inquisition was initially directed at conversos, moriscos, and later heretics considered an internal threat to the Catholic Church and the Spanish monarchy. A sort of the collusion

of convenience defines the history of the Spanish Crown and the Catholic Church, and specific policies to snuff out all dissent to the crown were swiftly adopted with the appointment of the first inquisitors in September of 1480 (Kamen 193-214).

The Portuguese Inquisition was characterized by an initially similar confluence of the Church and members of the royal family. For example, Manuel I's fifth son, Henrique, was one of the early inquisitors. He subsequently became king of Portugal in 1578 (upon the death of King Sebastião at al-Qasr al-Kebir), and he reigned until his death in 1580. Initially, the Portuguese Inquisition had three courts, in Lisbon, Coimbra, and Évora. The tribunal in Goa was created in 1560. It had jurisdiction over the territories that were in Portuguese possession east of the Cape of Good Hope, while inquisition authorities in Brazil, Congo, and Angola reported to the Lisbon tribunal.

One of the prominent features of the Portuguese Inquisition was the auto-dafé. It was a major display of the power of the ecclesiastical authorities in the matter of inquisition. The ritualistic aspects of this spectacle/procedure were meant to instill fear of inquisition in the heart of the society through the public penance of heretics, but it also involved physical punishments and even executions. The sermons that were given on the eve of these tragic spectacles were often printed and reprinted. Another set of printed responses also frequently 
followed these printed sermons. In case of Goa, we have a well-preserved account of the procedure in the 1687 work of French physician Charles Gabriel Dellon.

The first complaints of an inquisitorial nature in Angola and Congo were registered between 1620 and 1632 (Bethencourt and Havik; IANTT mf.7423. mç. 9, doc 8). The archival folios that document these denuncias are found at the Torre de Tombo, and Tahinan da Cruz Santos has described these documents as they applied to the inquisitorial practices against the local non-Catholic, nonChristian rituals that were practiced in Congo. These were complaints filed against local rituals in the territory before and during the Portuguese rule.

The Inquisition in the Portuguese imperial context cannot be seen as a uniform process throughout the colonies due to the historical specificities, the distances, and the infrastructural deviations when it came to enforcing dogma throughout the empire. While the metropole made every effort to enforce its dogmatic principles within the colonies, there are nonetheless periodic differences throughout the history of the Portuguese Inquisition. The discussion of the general periodization is beyond the scope of this essay; however, it is sufficient to state that the trajectory of the Inquisition was nuanced. For example, when King João IV prohibited the confiscation of the personal property by the Inquisition authorities in 1649, he was excommunicated by the Pope. (Saraiva 214; Azevedo). One must also remember that from 1580 to 1640, the Spanish Crown controlled Portugal. Thus, the Inquisition in Portugal remained during this period under the influence of the Spanish crown. We also know that in 1602, the Spanish crown accepted a gift of the large sum of money from a community of Jews that resulted in the release of 410 prisoners from the Inquisitorial inquiry (Kamen 358).

The eighteenth- and nineteenth-century Inquisition in Portugal and its colonies continued. However, the numbers of those who were tried dropped significantly between 1780 and 1820 (Kamen 370). The ascent of the Marquis of Pombal (1699-1782) led to gradual religious liberalization (Henn 62). We know, for example, that he made the institutions and their ability to implement the trials subordinate to the Portuguese Crown (Toby 331). We also note that the Napoleonic invasions of Spain and Portugal affected the Inquisition in the region. From 1807 until 1811, with the defeat of Napoleon and the ensuing turmoil, the Inquisition and its institutions weakened. 
Goa was occupied by the British during the Napoleonic Wars, and they abolished the Goan Inquisition in 1812. Following the liberal revolution in 1820, Portugal abolished the Inquisition in the metropole and its colonies. The types of punishments, their duration, and the individuals that were tried are equally important, but these fall beyond the scope of the present essay.

\section{Select Online Sources and Records}

Online sources enable and enhance the ability of users to interact with texts, often without leaving the workspace. The records that are related to the Inquisition are grouped below into two broad groups. Within each group, I have also added the geographic location as required. Before discussing these groups, however, it is worth singling out Inquisitio, an online collection of manuscript and print sources for the study of Inquisition history at the University of Notre Dame. According to the site itself, Inquisitio's purpose is as follows:

The materials featured on this website are from the University of Notre Dame's Harley L. McDevitt Inquisition Collection. The collection consists of several hundred items, from printed volumes to unique manuscripts and images, all bearing some relationship to the general theme of 'Inquisition.' For the most part, the documents were produced by the Spanish Inquisition or its critics, though several pieces also relate to other regions. Thanks to the generosity of Harley L. McDevitt, Notre Dame was able to purchase the collection as a whole in 1997. Its contents comprise one of the world's most important and distinctive private collections for Inquisition studies.

The site provides access to a searchable database of the related documents, and while it provides access to various thematic documents related to the Spanish Inquisition, its coverage of Portugal seems to be limited. As of 2019, there were only 18 items related to the Portuguese Inquisition in its archive.

Most of the documents catalogued in Inquisitio are in print format. There are only two manuscripts. However, most of the content of the many materials that are part of this collection can be seen online without any specific requirements. 
Along with Inquisitio, there are other sites with materials, such as the limited manuscript collections at the University of Pennsylvania ("Penn In Hand"), Brown University (John Carter Brown Library: Portugal And Brazil Collection), and others. However, I have tried in what follows to focus on collections with substantial materials related to the Portuguese Inquisition.

\section{Primary Sources}

The Arquivo Nacional da Torre de Tombo in Lisbon is the largest repository of materials related to the Portuguese Inquisition. It offers several digitized resources on the Inquisition. While several of these resources can be accessed physically, there is a litany of resources that have been digitized and made available for researchers through the Open Access model. These digitized resources are indexed and are searchable in the DigitArq database.

One of the relevant procedural aspects of the Inquisition is that the prosecutor's office in cities where the Inquisition tribunal was established had to document different types of complaints and accusations that were made against supposed heretics in a resource known as the Cadernos do Promotor. In the image below, we see that all 139 "complaint books" for the years 1541 through 1832 are searchable.

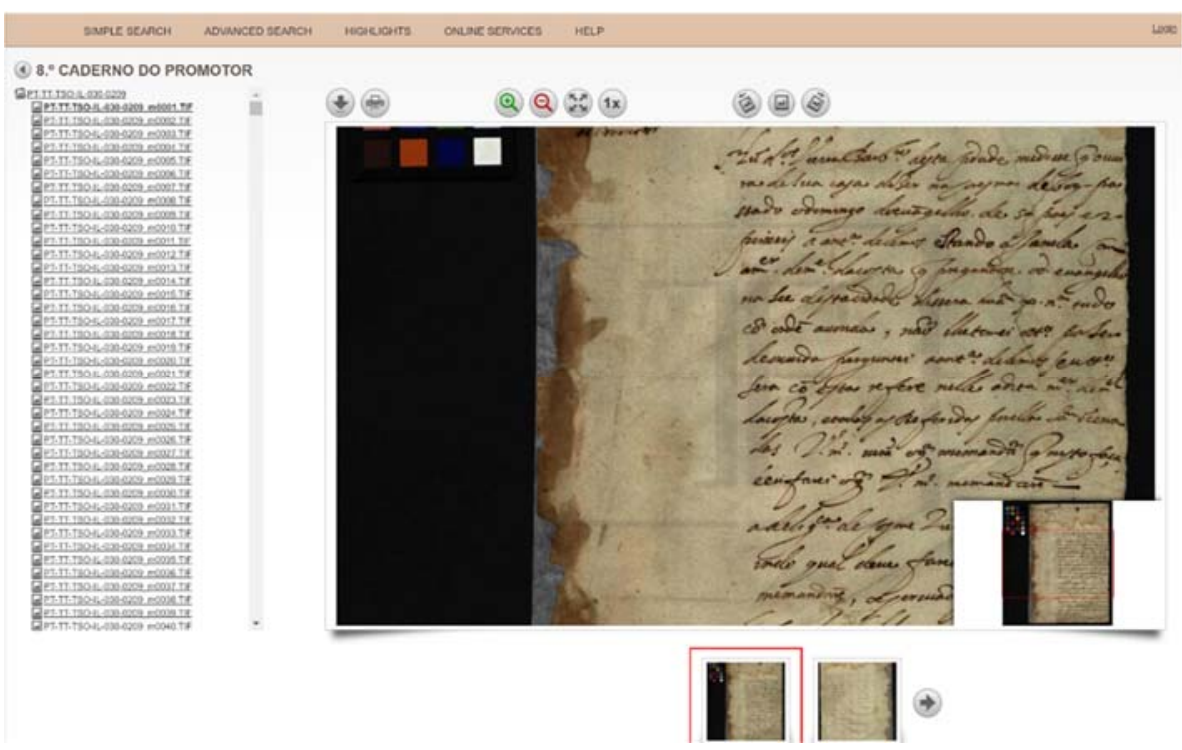


The records are indexed under Tribunal do Santo Ofício 1536/1821. As shown in the image above, each caderno has been digitized and arranged by the date. The view option likewise allows one to see the digitized notebook in greater detail. Also, one can print or download individual TIFF images for personal use. Beyond this, it is possible to request a consultation of the physical notebook in advance or request reproduction of the image.

Similar documents have likewise been digitized for the Coimbra tribunal, as well. The arrangement of the documents is identical to that of Lisbon, and its very logical Ministros e oficiais section revolves around the bureaucratic apparatus of the Inquisition. It brings together all the documents in the series related to the management of officials associated with the inquisitorial apparatus (inquisitors, deputies, prosecutors, commissioners, and notaries), as well as agents (family members). The second section is that of the Juízo do Fisco. In this section, some sub-sections allude to and provide access to the various documents, including the juridical processes, trials, procedures, penalties, complaints, etc. One must note that not all the records have been digitized and made accessible from an off-site location. Thus, the advanced search feature of the database acquires importance, as one can search for the digital representation of an item when it is available.

There are several other vital sources on the Portuguese Inquisition. One of them is the digital component of the National Library of Brazil, where one can find relevant digitized documents associated with the Inquisition in Goa. According to Patricia Souza de Faria, the collection on the Portuguese Inquisition in Goa "acolhe nove volumes encadernados de originais e cópias da correspondência trocada entre o Conselho Geral da Inquisição de Lisboa e a Mesa da Inquisição de Goa, além de breves papais, alvarás régios, provisões, listas de réus e ordens diversas sobre a gestão dos assuntos do Santo Ofício nas terras asiáticas." She goes on to claim that the "conjunto disponível na Seção de Manuscritos da Biblioteca Nacional abrange os séculos XVI a XIX e é composto por aproximadamente 1.600 documentos [e são os códices com notação de $25,1,001$ a 25,1,009]."

The Portuguese National Library is another repository that hosts a small selection of digitized documents. There are currently only twelve documents digitized and accessible without restrictions, among them a 1621 letter from Bishop Fernão Martins Mascarenhas, then the Inquisitor General for Portugal, 
prohibiting the circulation of an anonymous manuscript that his office considers to be "atentório contra os maus costumes e piedade cristã" (Lisbon, BN res-12022-a).

Primary sources are of extreme importance; however, secondary sources allow us to triangulate the data that we find in the primary sources. These also help with the location of the various primary sources. Other than the official documents of the Inquisition, the memoirs of eyewitnesses are also important primary sources. Several well-known memoirs are available digitally, such as Francis Blyth's 1761 Authentic Memoirs Concerning the Portuguese Inquisition Never Before Published, of which there are multiple digital copies available through the websites of the Hathi Trust as well as at the Portuguese National Library. Another important book accessible in its digitized version is the English translation of Dellon's 1687 acount of the Inquisition of Goa and his escape from its custody. Dellon, a French physician and traveler, describes in detail the various aspects of the Inquisition in Goa, including his trial for heresy and subsequent imprisonment by the Portuguese.

\section{Secondary Sources}

There are several secondary sources and accounts of the Portuguese Inquisition available online. Below are some of the repositories of such resources, which shed light on the Inquisition in various parts of the Portuguese Empire.

The HathiTrust remains a unique repository of the secondary materials on Portuguese Inquisition. There are currently 1,138 full-text items available. Items published in English, however, constitute over $98 \%$ of the total items available there. Ironically, items in Portuguese make up only $0.44 \%$ of the total. This result was obtained through a search for "Portuguese Inquisition," but when one repeats the search without quotation marks in full-text and all fields, one gets 194,638 items in the full-view category. Out of these full-view items, 189,327 are in English, and 226 are in Portuguese. One note of caution is that searching for "Portuguese Inquisition" as a term without the quotation marks also renders results that are not directly related to the Portuguese Institution.

Besides the Hathi Trust, there are other Open Access resources such as the European Library, but the coverage related to the Portuguese Inquisition is limited. In all, there are 149 items in different categories of the European Library. 
Of these 149 items, 29 are accessible online. However, the limitation of this online resource becomes self-evident when one tries to examine these materials. Many of them are a mere repetition of the same items.

\section{Conclusion}

The Portuguese Inquisition spanned over four continents and lasted for four centuries. It created a vast array of documentary evidence that allows researchers to understand to a great degree its mechanisms and structures. Digital access based on principles of open access enables multiple researchers to access these digital documents, further enhancing our understanding of the slightly different trajectories of regional Inquisition apparatuses throughout the Portuguese Empire. The secondary literature on the Portuguese Inquisition, available through the same principles of open access, serves as a sort of pathfinder for the primary sources while providing further contextual analysis. Taken together, these sources present an anatomy of the Inquisition and its different modalities in varying geographic contexts. These resources, therefore, constitute a powerful pedagogical and investigative tool on the Portuguese Inquisition.

\section{Works Cited}

Aparecida de Silveira, Sonia. "A disciplina da vida colonial: os regimentos da Inquisição.” Revista do Instituto Histórico e Geográfico Brasileiro, vol. 157, no. 392, 2019, pp. 497-973.

Axelrod, Paul, and Michelle A. Fuerch. "Flight of the Deities: Hindu Resistance in Portuguese Goa." Modern Asian Studies, vol. 30, no. 2, 1996, pp. 387421.

Azevedo, João L. História dos christãos novos portugueses. Teixeira, 1921, archive.org/stream/historiadoschris00azev\#page/236.

Baião, António. A Inquisição de Goa: tentativa de história da sua origem, estabelecimento, evolução e extinção. Academia das Ciências, 1930.

Bethencourt, Francisco, and Philip Havik. "A África e a Inquisição portuguesa: novas perspectivas." Revista Lusófona de Ciência das Religiões, 2004, recil.ulusofona.pt/bitstream/handle/10437/5595/africa_inquisicao_portugue sa.pdf? sequence $=1$. 
Blyth, Francis. Authentic Memoirs Concerning the Portuguese Inquisition, Never Before Published. Murray, 1761.

Coelho Moreno, Carmen Tereza. "Inquisição de Goa." Anais da Biblioteca Nacional, vol. 120, 2000, pp. 7-222.

Dellon, Charles Gabriel. Relation de l'Inquisition de Goa. Gaasbeck, 1687.

- The History of the Inquisition, as it is Exercised at Goa. Translated by Henry Wharton, Baldwin, 1750.

Henn, Alexander. Hindu-Catholic Encounters in Goa: Religion, Colonialism and Modernity. Indiana UP, 2014.

Herculano, Alexandre. História da origem e estabelecimento da Inquisição em Portugal. Imprensa Nacional, 1854.

"Inquisitio: Manuscript and Print Resources for the Study of Inquisition History." $\mathrm{U}$ of Notre Dame, inquisition.library.nd.edu/collections/RBSCINQ :COLLECTION.

"John Carter Brown Library: Portugal And Brazil Collection."Archive.org, archive.org/ details/jcbportugalbrazil.

Kamen, Henry. The Spanish Inquisition: A Historical Revision. Yale UP, 2014.

Lisbon, Biblioteca Nacional. "Circular do Santo Ofício, proibindo a posse, leitura e circulação de um libelo considerado atentório contra os maus costumes e piedade crista." BN res-1202-2-a, purl.pt/17423.

Lisbon, Instituto Arquivo Nacional da Torre do Tombo (IANTT). "Denunciações do Reino do Congo e Angola." Tribunal do Santo Ofício, Inquisição de Lisboa, mf.7423. mç. 9, doc 8, digitarq.arquivos.pt/details?id=2318699.

Marcocci, Giuseppe. "Toward a History of the Portuguese Inquisition: Trends in Modern Historiography (1974-2009)." Revue de l'Histoire des Religions, vol. 227, no. 3, 2010, pp. 355-93.

Mendonça, José Lourenço Domingues de, António J. Moreira, and João PalmaFerreira. História dos principais actos e procedimentos da Inquisição em Portugal. Imprensa Nacional-Casa da Moeda, 1980.

Murphy, Cullen. God's Jury: The Inquisition and the Making of the Modern World. Mariner, 2013.

O'Banion, Patrick J. This Happened in My Presence: Moriscos, Old Christians, and the Spanish Inquisition in the Town of Deza, 1569-1611. U of Toronto P, 2017. 
"Penn In Hand: Selected Manuscripts." U of Pennsylvania, dla.library .upenn.edu/dla/medren/search.html?q=portuguese+inquisition.

Santos, Tahinan da Cruz. "Inquisição Portuguesa na África: denunciações do Reino do Congo E Angola No Século XVII.” Revista Cadernos de Clio, vol. 2, no. 1, 2011, dx.doi.org/10.5380/clio.v2i1.40483.

Saraiva, António José. The Marrano Factory: The Portuguese Inquisition and its New Christians: 1536-1765. Translated by Herman Prins Salomon, Brill, 2001.

Souza, Grayce Mayre Bonfim. Para remédio das almas: comissários, qualificadores e notários da Inquisição Portuguesa na Bahia colonial. 2014. U Estadual do Sudoeste da Bahia. PhD. www.catedra-alberto-benveniste.org $\% 2 \mathrm{~F}$ _fich\%2F $17 \% 2 \mathrm{FTese}$ Grayce_Souza_-_Para_remedio_das_almas__Comissarios_Qualificadores.pdf.

Souza de Faria, Patricia. "O tribunal da Inquisição de Goa através dos manuscritos da Biblioteca Nacional.” BNDigital, 12 Mar. 2014, bndigital.bn.gov.br/artigos/o-tribunal-da-inquisicao-de-goa-atraves-dosmanuscritos-da-biblioteca-nacional/.

Townsend, George H. The Manual of Dates: A Dictionary of Reference to All the Most Important Events in the History of Mankind to Be Found in Authentic Records. Warne, 1877.

Wadsworth, James E. "In the Name of the Inquisition: The Portuguese Inquisition and Delegated Authority in Colonial Pernambuco, Brazil." The Americas, vol. 61, no. 1, 2004, pp. 19-54. 